\title{
Marinas as habitats for nearshore fish assemblages: comparative analysis of underwater visual census, baited cameras and fish traps
}

\author{
Néstor E. Bosch ${ }^{1,2}$, Jorge M.S. Gonçalves ${ }^{2}$, Fernando Tuya ${ }^{1}$, Karim Erzini ${ }^{2}$ \\ ${ }^{1}$ Grupo en Biodiversidad y Conservación, IU-ECOAQUA, Universidad de Las Palmas de Gran Canaria, \\ 35017 Las Palmas de G.C., Canary Islands, Spain. \\ (NEB) (Corresponding autor) E-mail: nbosch1989@ gmail.com. ORCID-iD: http://orcid.org/0000-0003-0421-8456 \\ (FT) E-mail: ftuya@yahoo.es. ORCID-iD: http://orcid.org/0000-0001-8316-5887 \\ ${ }^{2}$ Centro de Ciências do Mar (CCMAR), Universidade do Algarve, Campus de Gambelas, 8005-139 Faro, Portugal. \\ (JG) E-mail: jgoncal@ualg.pt. ORCID-iD: http://orcid.org/0000-0001-7704-8190 \\ (KE) E-mail: kerzini@ualg.pt. ORCID-iD: http://orcid.org/0000-0002-1411-0126
}

\begin{abstract}
Summary: Understanding the ecological role that artificial structures might play on nearshore fish assemblages requires the collection of accurate and reliable data through efficient sampling techniques. In this work, differences in the composition and structure of fish assemblages between the inner and outer sides of three marinas located in the temperate northern-eastern Atlantic Ocean were tested using three complementary sampling techniques: underwater visual censuses (UVC), baited cameras (BCs) and fish traps (FTs). UVCs and BCs recorded a comparable number and relative abundance of species, which in turn were much greater than those recorded by FTs. This finding supports the use of UVCs and BCs over FTs for broad ecologically studies, especially when dealing with structurally complex habitats such as artificial structures. We found differences in fish assemblage structure between the inner and outer sides of marinas, independently of the sampling method. Four small-sized species (Similiparma lurida, Thalassoma pavo, Sarpa salpa and Symphodus roissali) associated with structurally complex vegetated habitats dominated, in terms of abundance, the outer sides of marinas; Diplodus vulgaris, Diplodus sargus and Gobius niger, species with high ecological plasticity in habitat requirements, dominated the inner sides of marinas. The information provided in this study is of great interest for developing sound monitoring programmes to ascertain the effects of artificial structures on fish communities.
\end{abstract}

Keywords: coastal development; marinas; habitat loss; fish assemblages; sampling methods; sampling efficiencies.

Los puertos deportivos como hábitats para comunidades de peces litorales: análisis comparativo de censos visuales, cámaras con cebo y trampas para peces

Resumen: La comprensión de papel ecológico que las estructuras artificiales pueden desempeñar en las comunidades de peces litorales requiere la recolección de datos precisos y fiables, a través de técnicas de muestreo eficientes. En este trabajo, las diferencias en la composición y estructura de los poblamientos de peces entre las caras interior y exterior de tres puertos deportivos situados en el océano septentrional Atlántico templado se investigaron mediante tres técnicas de muestreo complementarias: censos visuales (UVC), cámaras con cebo (BC) y trampas para peces (FT). UVC y BC registraron un número comparable de especies y abundancias relativas, que fueron mucho mayores que las registradas por FT. Esta mayor cantidad de datos recogidas apoya el uso de estas técnicas sobre FT en estudios ecológicos, especialmente cuando se trata de hábitats de elevada complejidad estructural como el caso de estructuras artificiales. Encontramos diferencias en los poblamientos de peces entre las caras interior y exterior de los puertos deportivos, independientemente del método de muestreo. Cuatro especies de pequeño tamaño (Similiparma lurida, Thalassoma pavo, Sarpa salpa and Symphodus roissali), asociadas a hábitats vegetales estructuralmente complejos, dominaron, en términos de abundancia, las caras exteriores de los puertos deportivos; Diplodus vulgaris, Diplodus sargus y Gobius niger, especies con alta plasticidad ecológica en los requerimientos del hábitat, dominaron las caras interiores. La información aportada en este estudio es de gran interés para desarrollar programas de monitoreo adecuados para determinar los efectos de las estructuras artificiales en las comunidades de peces.

Palabras clave: desarrollo costero; puertos deportivos; pérdida de hábitat; poblamientos de peces; métodos de muestreo; eficiencias de muestreo.

Citation/Como citar este artículo: Bosch N.E., Gonçalves J.M.S., Tuya F., Erzini K. 2017. Marinas as habitats for nearshore fish assemblages: comparative analysis of underwater visual census, baited cameras and fish traps. Sci. Mar. 81(2): 159-169. doi: http://dx.doi.org/10.3989/scimar.04540.20A

Editor: E. Macpherson.

Received: August 23, 2016. Accepted: January 18, 2017. Published: April 6, 2017.

Copyright: () 2017 CSIC. This is an open-access article distributed under the terms of the Creative Commons Attribution (CC-by) Spain 3.0 License. 


\section{INTRODUCTION}

As human settlements increase in coastal areas, anthropogenic activities contribute to the alteration of the coast through pollution, habitat conversion and depletion of natural resources. One of the major threats associated with coastal development is the loss of natural habitats through the construction of artificial structures, such as marinas and breakwaters (Airoldi and Beck 2007, Halpern et al. 2008). Habitat conversions may result in profound changes in the composition and structure of natural communities, which in turn have effects on biodiversity, altering underlying ecosystem functions and services (Courrat et al. 2009, Seitz et al. 2014). Thus, it is becoming increasingly important to understand the extent to which artificial structures might fulfil the ecological roles provided by natural habitats.

The potential benefits of artificial structures on fish assemblages have been drawing the attention of many researchers in the last few decades. A large number of studies have focused on the role of artificial structures such as fish attracting devices (Carr and Hixon 1997, Rilov and Benayahu 2000) and their contribution to increasing fish biomass (Bohnsack 1989). Though marinas are among the most widespread artificial structures along the shoreline of the world, studies focusing on fish assemblages associated with marinas are still scarce (Clynick 2006, 2008, Bouchoucha et al. 2016). Breakwaters at the outer sides of marinas are frequently colonized by a range of fishes, at both juvenile and adult stages (Pizzolon et al. 2008, Cenci et al. 2011, Pastor et al. 2013). The inner sides of marinas, on the other hand, offer shallow and protected habitats, which can be suitable as nursery grounds for some fish species (Bouchoucha et al. 2016). In addition to direct impacts on natural shallow habitats, marinas can indirectly change local current patterns and increase sediment loads, which in turn have drastic consequences on the composition of benthic communities (Connell and Glasby 1999), altering the distribution, abundance and diversity of associated fauna (Clynick et al. 2007). Some works have argued that the different structures found in marinas, such as docks and pontoons, may provide novel habitats that are suitable for several fish species. Most of these studies have shown that artificial habitats can support a subset of the fish species that occur in the adjacent natural habitats (Clynick 2008, Wakefield et al. 2013), in variable relative abundances depending on species-specific requirements for shelter, reproduction and diet (Connell and Glasby 1999). It has therefore been suggested that artificial habitats, such as marinas, might support certain ecological functions, hence minimizing the effects of habitat loss.

Several methods exist for monitoring fishes at shallow depths (Murphy and Jenkins 2010), including nonextractive methods, such as underwater visual census techniques (hereinafter UVCs) and baited cameras (hereinafter BCs), and extractive fishing techniques, such as fish traps (hereinafter FTs). UVCs are the most commonly used procedure, as they allow a rapid, cheap and replicable acquisition of several quantitative varia- bles simultaneously (e.g. relative abundances, size and habitat characteristics) (Harmelin-Vivien et al. 1985). However, they involve certain sources of bias, such as species-specific adaptations to diver presence, in situ species misidentification and inter-observer variability in abundance and size estimates (Edgar et al. 2004), which in turn can affect the suitability of the data and compromise our ability to detect significant changes in an ecological study (Langlois et al. 2010, Wakefield et al. 2013). Though this is widely acknowledged, most studies focusing on fish assemblages associated with artificial structures have exclusively relied on UVC techniques. Recently, technological improvements have made baited video equipment more affordable, and this technique has been used in a range of ecological studies. Video cameras can effectively sample topographically complex and sensitive habitats (Cappo et al. 2006), but their use in studies of artificial structures has been limited (Lowry et al. 2012, Wakefield et al. 2013). Finally, FTs have been traditionally used to assess demersal fish assemblages, particularly in deep waters (Harvey et al. 2012, Bacheler et al. 2013), but their high selectivity and variable catchability might reduce their statistical power for detecting significant effects (Harvey et al. 2012, Wakefield et al. 2013).

In this work, we studied fish assemblages on the inner and outer sides of three marinas located in two different ecoregions within the Lusitanian province in the temperate northern-eastern Atlantic Ocean: Gran Canaria (Canary Islands) and southern Portugal (Algarve coast). Differences in the composition and structure of fish assemblages were tested using three complementary sampling techniques (UVCs, BCs and FTs). This allowed us to test for differences in the composition and structure of fish assemblages between sides of the marinas by varying sampling techniques in two ecoregions under varying environmental settings. Comparisons presented in this study provide insights into the role of artificial structures on sustaining fish assemblages, as well as providing information on the efficiency of different sampling methods in discriminating community patterns associated with artificial structures. This type of information is essential to develop sound monitoring programmes to ascertain the ecological role played by artificial habitats.

\section{MATERIALS AND METHODS}

\section{Study area}

This study was carried out in two ecoregions within the Lusitanian province in the temperate northerneastern Atlantic Ocean: the Canarian archipelago and the Algarve coast (southern Portugal). In the Canarian archipelago, the study was undertaken at Gran Canaria island. This island is characterized by a narrow continental shelf; the shallow sublittoral zone is mainly composed of basaltic hard bottoms and extensive sand bottom habitats, with a high variability in the distribution and complexity of these habitats, which can be covered by a range of canopy-forming species (Tuya and Haroun 2006). The Algarve coast comprises 


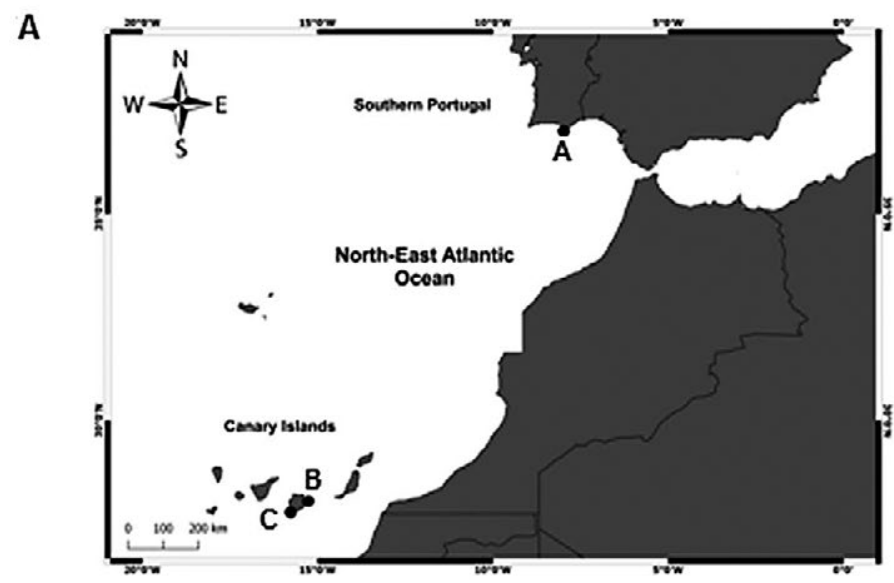

B

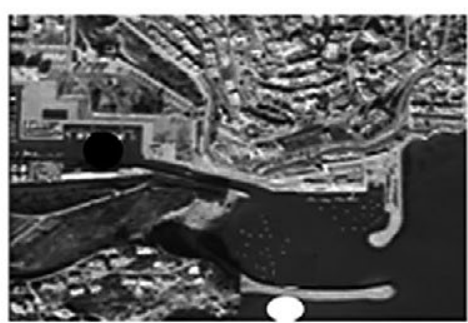

C

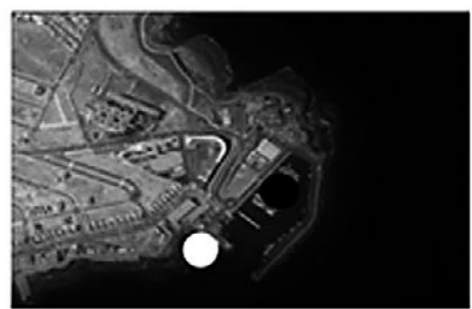

D

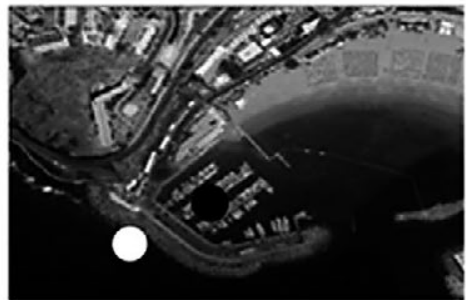

Fig. 1. - Location of marinas in southern Portugal (Albufeira, A) and Gran Canaria (Taliarte, B and Puerto Rico, C), including inner (black symbols) and outer sides (white symbols) of Albufeira (B), Taliarte (C) and Puerto Rico (D).

around $200 \mathrm{~km}$ of coastline, characterized by extensive sandy beaches interspersed by limestone reefs (Monteiro et al. 1987).

At Gran Canaria, we selected two marinas: Taliarte $\left(27^{\circ} 59^{\prime} 25.74^{\prime \prime} \mathrm{N}, 1^{\circ} 22^{\prime} 05.37^{\prime \prime} \mathrm{W}\right)$ and Puerto Rico $\left(27^{\circ} 59^{\prime} 25.74^{\prime \prime} \mathrm{N}, 15^{\circ} 22^{\prime} 05.37^{\prime \prime} \mathrm{W}\right)$. In southern Portugal, we selected one marina: Albufeira $\left(37^{\circ} 05^{\prime} 02.90^{\prime \prime} \mathrm{N}\right.$, $\left.8^{\circ} 16^{\prime} 03.55^{\prime \prime} \mathrm{W}\right)$ (Fig. 1A). At each marina, we selected two sides, corresponding to the inner (inland) and outer (open ocean) sides of marinas (Fig. 1B, C, D). For practical reasons, only one sector of the Albufeira marina was selected (see details in Fig. 1B). All the marinas are of similar size $\left(<0.1 \mathrm{~km}^{2}\right)$ and, despite their specific spatial configuration, all of them are composed of floating pontoons and small boulders in the inner parts, and large concrete blocks in the outer parts.

\section{Data collection}

Fish assemblages were evaluated during the summer of 2015 using three complementary sampling techniques: (i) UVCs, (ii) FTs and (iii) BCs. All samples were taken at a depth range of between 3 and $5 \mathrm{~m}$ and during daylight hours. The inner and outer sides of each marina were sampled on the same day, and the three marinas were sampled within a period of 1 to 4 weeks. The different survey methods were carried out over three consecutive days.

\section{UVCs}

At each side within each marina, $n=6,10 \mathrm{~m}$ length $\times$ $4 \mathrm{~m}$ wide, transects were deployed by SCUBA divers. Along each transect, we annotated the abundances of each fish species according to standard procedures for the study region and elsewhere (Tuya et al. 2005, 2011). Individual fish counts were done up to 20 individuals. The abundance of schooling species, such as the bogue, Boops boops, was estimated using abundance classes: 21-30, 31-40, 41-50, 51-100, 101-200 and $>200$. Fish size was estimated using size classes of $5 \mathrm{~cm}(0-5,5-10,10-15,15-20,20-25 \mathrm{~cm}$, etc.). Sea water visibility ranged between 8 and $15 \mathrm{~m}$ at Gran Canaria island; in southern Portugal, however, the visibility decreased from the outer ( 5 to $10 \mathrm{~m}$ ) to the inner ( 3 to $5 \mathrm{~m}$ ) side of the marina. To avoid bias, fish counts were not performed if the visibility was $<3 \mathrm{~m}$. Noncryptic species were first counted along each transect, while cryptic species were counted on the way back. In this case, small caves, ledges and overhangs were carefully inspected. Fishes that were not visually identified to species level were recorded as genera; each fish was then treated as a distinct species in the statistical analyses. Additionally, we recorded information on the habitat composition and structure for each fish count, i.e. the percent cover of algae, big blocks (BB, large topographic elements $>1 \mathrm{~m}$ ), small blocks ( $\mathrm{SB}$, small topographic elements $<1 \mathrm{~m}$ ), sand (S) and mud (M). The percent cover was visually estimated via the linear point intercept sampling technique (Ohlhorst et al. 1988). Along each 10-m-long transect, the diver annotated the type of substrate every metre (i.e. 10 points per transect). We used a functional group approach (Steneck and Dethier 1994) to describe algal coverage, attributing individual algal species into three morpho-functional groups previously used in the Canarian archipelago (Tuya and Haroun 2006). Turf algae (TA) consisted of small cushion-shaped and fila- 
mentous algae (e.g. Lobophora variegata, Colpomenia sinuosa, Codium sp.), usually $<5 \mathrm{~cm}$. Bush-like algae (BA) consisted of sheet-shaped, articulate non-crustose calcareous and thick leathery species (e.g. Asparagopsis sp., Dyctiota sp., Padina pavonica), ranging from 1 to $15 \mathrm{~cm}$ in height. Finally, crustose coralline algae (CCA) consisted of encrusting calcareous algae (e.g. Lithothamnion sp., Lithophyllum sp.).

FTs

We used circular, wire-framed, FTs (15 mm mesh size, $82.5 \mathrm{~cm}$ inner diameter $\times 53 \mathrm{~cm}$ height), including two funnel entrances and a door at the top to add bait and extract catches (Supplementary material Fig. S1).

At each side within each marina, $n=12$ at Gran Canaria, $n=6$ at southern Portugal, traps were dropped and subsequently retrieved after 2.5 h (Harvey et al. 2012, Bacheler et al. 2013). Each trap was baited with fresh Atlantic chub mackerel, Scomber colias, in the same proportion at Gran Canaria island and a mix of Atlantic chub mackerel, mussels (Mytilus edulis) and sardine oil (Sardina pilchardus) in southern Portugal. Adjacent traps were 10 to $15 \mathrm{~m}$ apart. All collected fishes were identified to the lowest taxonomic level and the total length (TL, cm) was measured with a rule. All captures were then released.

$B C s$

Single underwater BCs (Supplementary material Fig. S2) were placed horizontally on the seabed, as similarly reported by Cappo et al. (2006). The system consists of a main horizontal bar, which supports two vertical bars, both made of stainless steel, one containing a PVC container $(20 \mathrm{~cm}$ length $\times 10 \mathrm{~cm}$ height $)$ with the bait, and the other with a camera (Gopro Hero $3+$ ). A separation of $1 \mathrm{~m}$ between the bait and the camera was established to optimize the focus (field view), as fishes approach the camera. At both ends of the main bar, we placed stabilizing arms to ensure that the device landed horizontally on the seafloor. To increase the dispersion of the odour plume, the bait container was elevated above the seafloor. The main and vertical bait bar were both mounted with small scale-bars (scale grids of $2.5 \mathrm{~cm}$ long $\times 2.5 \mathrm{~cm}$ width).

At each side within each marina, $n=3, B C s$ were placed sequentially on the seafloor and recovered after $45 \mathrm{~min}$, in the same sequential order. Filming times of between 25 and $30 \mathrm{~min}$ were indicated to obtain accurate relative abundances of fish species (Stobart et al. 2007, Langlois et al. 2010). At Gran Canaria, once the BCs had been recovered, the same procedure was repeated on the same side but at different places $(n=6)$, to reach a total of 60 deployments and $27 \mathrm{~h}$ of video recording for the whole study. Adjacent BCs were between 10 and $15 \mathrm{~m}$ apart. Each bait container was filled with the same bait as the traps.

We used one-minute photo frames (at 10 Megapixels) to assess the relative abundances of fish species: the maximum number of each species in the field of view in a single frame for each sample (MaxN) was used as a measure of the relative abundances of species (Cappo et al. 2006). The freeware ImageJ was used to count individuals of each species present in each photo frame, using the cell counter plugin. In some cases, due to the poor quality of the images, the brightness and contrast had to be increased/decreased to facilitate fish identification. Fishes that were not identified to the level of species were recorded as genera; each was then treated as a distinct taxon in the statistical analyses. As for the UVCs, fish counts were not performed if visibility was $<3 \mathrm{~m}$. In this case, we used the distance to the bait arm $(1 \mathrm{~m})$ as a guide to estimate visibility. Fish size measurements were not attempted, as the use of a single camera to accurately estimate fish size is known to be greatly influenced by the relative position of the fish to the calibration bar (Harvey et al. 2002).

\section{Statistical analysis}

Differences in the mean total fish abundance (i.e. data pooled for all the species) between the inner and outer side of each marina, according to each sampling method, were tested through a two-way crossed ANOVA, including the factors 'Side' (fixed, inner vs. outer) and 'Method' (fixed, UVC vs. BC vs. FT). When significant 'SidexMethod' interactions were found, pairwise tests resolved differences between the inner and outer side of each marina. Pairwise comparisons also resolved differences between methods at each side of each marina. Prior to these analysis, the mean total fish abundance was standardized to z-scores using the mean and standard deviation to account for differences in sampling unit size between methods. The assumption of homogeneity of variances was checked by means of Corchan's test (Underwood 1981). When this was violated, data were $\log (\mathrm{x}+1)$ transformed. These analyses were carried out separately for each marina on $\mathrm{R}$ v3.2.3.

Species abundance data were square-root transformed to downweight the contribution of the most abundant species. From Bray-Curtis similarity matrices, multidimensional scaling (MDS) plots were carried out separately for each sampling technique to examine the separation of samples between the inner and outer sides of marinas. In the case of southern Portugal, due to the presence of a considerable number of samples with zero counts in FT data that yielded undefined values in the resultant similarity matrix, we used a zero-adjusted Bray-Curtis coefficient that includes a virtual dummy variable that is 1 for all objects (Clarke et al. 2006). Differences in fish assemblage structure between 'Side' (fixed factor, inner $v s$. outer) and 'Marina' (random factor, orthogonal to 'Side') were tested through permutational multivariate analysis of variance (PERMANOVA, via 999 permutations of the raw data, Anderson 2001). When significant interactions were detected, pairwise tests were used to test for significant differences between the inner and outer side of each marina. Similarity percentage (SIMPER) analyses were used for each sampling method separately to identify which species contributed to differences in fish assemblage structure 
between the inner and outer side of the marinas. The criterion for considering a species a good discriminator was based on dissimilarity to standard deviation ratios (Diss/SD) close to 1 and percentage contributions $>5 \%$ (Watson et al. 2005).

To investigate the strength and significance of relationships between the set of environmental predictor variables and the fish assemblage structure, we undertook a distance-based multivariate analysis (DISTLM, Anderson 2001). This analysis was only undertaken for UVC data as it provides quantitative measures of the habitat type, while $\mathrm{BC}$ can only provide qualitative information, and FT does not provide any information. Significant predictor variables were selected using a stepwise selection procedure, with the choice of the final model based on the Akaike information criterion, in order to choose the most parsimonious model (Chambers and Hastie 1993). Prior to this analysis, percent cover data was arcsin $(\sqrt{x})$ transformed. Environmental predictor variables with correlations $>0.80$ were identified through draftsman's plots and excluded from the final analysis (Leathwick et al. 2006). Then, distance-based redundancy analysis (dbRDA) was applied to visualize the fitted model in the multidimensional space; partial correlations of significant environmental variables were overlaid on the graph as vectors to facilitate interpretation. To establish species-habitat associations, the abundances of fish species, identified as important contributors in the SIMPER analysis in UVC, were correlated with the dbRDA axes using a Pearson correlation coefficient (r) and overlaid on the dbRDA ordination plot. It must be noted that the correlation of environmental variables with the dbRDA axes was in some cases negative, and species correlations may therefore appear reversed. The MDS plots and SIMPER analyses were carried out by means of the PRIMER 6 software (Clarke and Warwick 2001); PERMANOVA, DISTLM and dbRDA were run on R using the 'vegan' package v2.3-4.

\section{RESULTS}

\section{Assemblage level patterns}

Differences in the mean total fish abundance between the inner and outer sides of marinas were sitespecific and varied among sampling methods (Fig. 2) ('Side $\times$ Method', $P<0.05$, Table 1 ). In the pairwise comparisons, there were no significant differences between UVCs and BCs at most sides within each marina $(\mathrm{P}<0.05$, Table 1$)$. These methods recorded a comparable number and relative abundance of species at the inner and the outer sides of Puerto Rico and Taliarte, while FTs recorded a considerably lower number (Fig. 2A, B). At Albufeira, UVCs, BCs and FTs recorded a comparable number of species, which were considerably lower than the species recorded at Gran Canaria island (Fig. 2C). Interestingly, species that were recorded by BCs and/or FTs but not by UVCs included piscivorous species such as the European conger (Conger conger), the dusky grouper

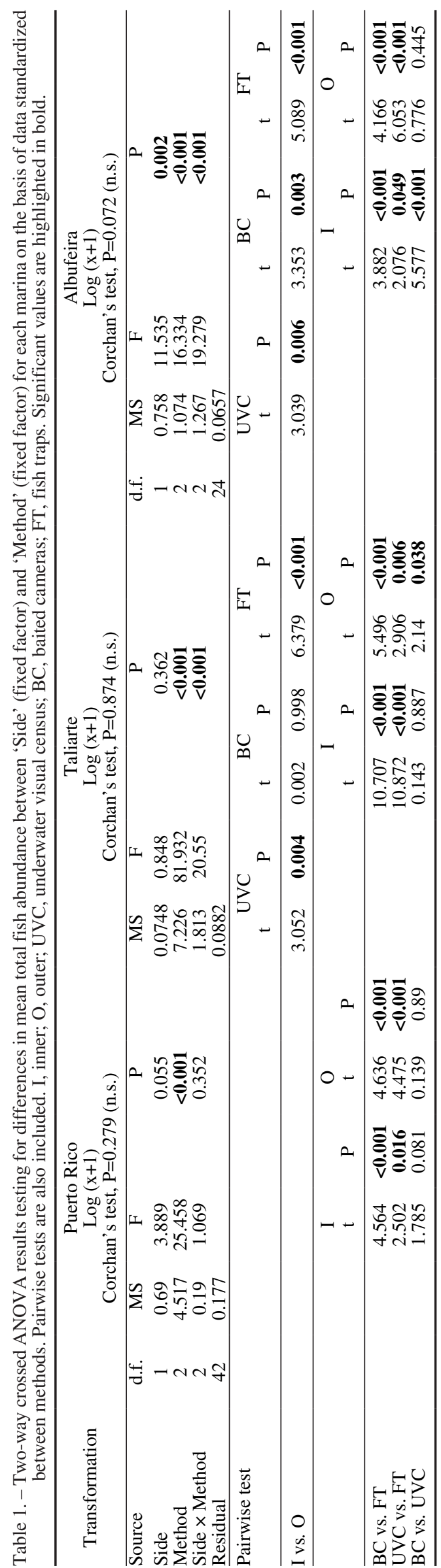




\section{Puerto Rico}
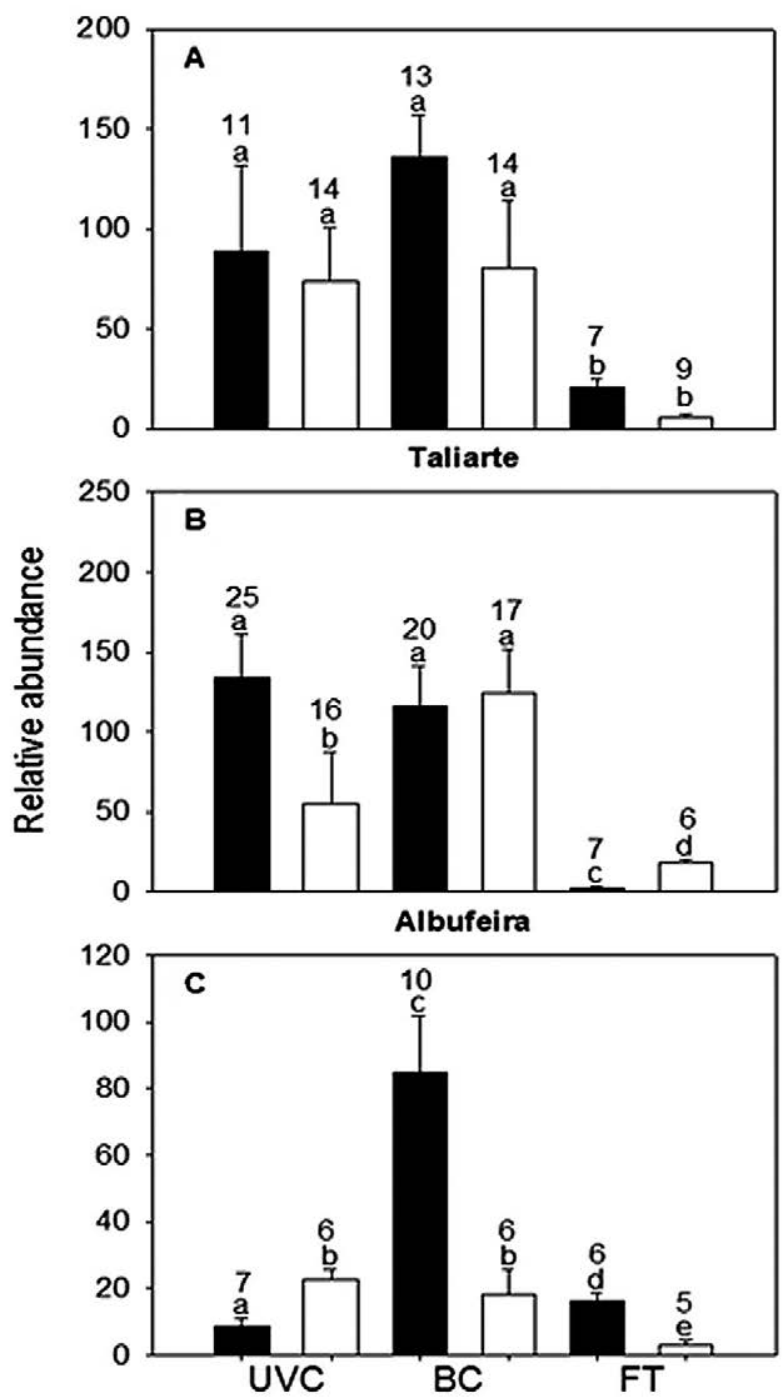

Fig. 2. - Mean (+SE) unstandardized total abundances of fishes at the inner (filled symbols) and outer (unfilled symbols) sides of Puerto Rico (A), Taliarte (B) and Albufeira (C) (UVCs, numbers per transect; BCs, Nmax; FTs, numbers per trap). Different letters above bars denote statistically significant differences. The number of species at each side of each marina is also shown above bars.

(Ephinephelus marginatus), the brown moray (Gymnothorax unicolor), the moray (Muraena augusti), the blacktail comber (Serranus atricauda) and the yellow mouth barracuda (Sphyraena viridensis) (Fig.
3). Conversely, species that were recorded by UVCs but not by BCs and/or FTs included cryptic species, such as the red-mouthed goby (Gobius cruentatus), the rock goby (Gobius paganellus), the tompot blenny (Parablennius gattorugine) and the scorpionfish (Scorpaena spp.1) (Fig. 3).

Two distinct groups of samples can be observed in the MDS ordination plots for UVC and $\mathrm{BC}$, corresponding to samples from Gran Canaria (left side) and southern Portugal (right side) (Fig. 4A, B). Within each ecoregion, the ordination plots consistently separated fish faunas, in terms of their assemblage structure, between the inner and outer sides of marinas. In the case of FTs, samples were more scattered over the ordination space and no apparent separation between regions was observed (Fig. 4C); the separation of fish faunas between the inner and outer sides of marinas was still noticeable. Though differences in fish assemblage structure between sides varied from marina to marina ('Marina $\times$ Side', $\mathrm{P}<0.05$, Table 2), pairwise tests for each sampling method showed differences in fish assemblage structure between the inner and outer sides of all marinas, except for Albufeira for the BC dataset $(\mathrm{P}<0.05$, Table 2).

The SIMPER results indicated that the number of taxa contributing to dissimilarities between the inner and outer sides of marinas, and their individual contributions, varied between marinas and sampling methods in both regions (Table 3). Two small-sized species, the ornate wrasse (Thalassoma pavo) and the Canary damselfish (Similiparma lurida), were consistent (i.e. for all sampling methods) contributors to dissimilarities between sides of the marinas at Gran Canaria island; these two species dominated the outer sides of the marinas. Other important contributors identified by either one or two of the sampling methods included the bogue (Boobs boobs), the two-banded seabream (Diplodus vulgaris), the white seabream (Diplodus sargus) and the black goby (Gobius niger), which dominated the inner sides of the marinas (Fig. 3); and the saupe (Sarpa salpa) and the Azores chromis (Chromis limbata), which characterized the outer sides (Fig. 3). From these species, $D$. sargus, D. vulgaris, G. niger and S. salpa were also important contributors to dissimilarities in southern Portugal, along with the sand smelt (Atherina presbyter), which characterized the inner side (Fig. 3), and the five-spotted wrasse (Symphodus roissali), which characterized the outer sides (Fig. 3). Interestingly,

Table 2. - Two-way crossed PERMANOVA results testing for differences in fish assemblage structure between 'Side' (Si, fixed factor) and 'Marina' (Ma, random factor) for each sampling method. Pairwise tests are also included. PR, Puerto Rico; TA, Taliarte; A, Albufeira; I, inner; $\mathrm{O}$, outer. Significant values are highlighted in bold.

\begin{tabular}{|c|c|c|c|c|c|c|c|c|c|c|c|c|c|}
\hline \multirow[b]{2}{*}{ Source } & \multicolumn{3}{|c|}{ UVC } & \multirow{2}{*}{\multicolumn{2}{|c|}{$\mathrm{P}$}} & \multirow[b]{2}{*}{ d.f. } & \multicolumn{3}{|c|}{$\mathrm{BC}$} & \multirow[b]{2}{*}{ d.f. } & \multicolumn{3}{|c|}{ Traps } \\
\hline & d.f. & MS & Pseudo-F & & & & MS & Pseudo-F & $\mathrm{P}$ & & MS & Pseudo-F & $\mathrm{P}$ \\
\hline $\mathrm{Si}$ & 1 & 20072 & 2.3165 & & 192 & 1 & 13246 & 1.8939 & 0.221 & 1 & 16949 & 1.2936 & 0.304 \\
\hline Ma & 2 & 16311 & 11.105 & & 001 & 2 & 10148 & 14.015 & 0.001 & 2 & 12310 & 10.425 & 0.001 \\
\hline $\mathrm{Si} \times \mathrm{Ma}$ & 2 & 8664.8 & 5.8993 & & 001 & 2 & 7412.2 & 10.237 & 0.001 & 2 & 13897 & 11.768 & 0.001 \\
\hline Residual & 30 & 1468.8 & & & & 24 & 724.08 & & & 54 & 1180.8 & & \\
\hline \multirow[t]{2}{*}{ Pairwise tests } & \multicolumn{2}{|r|}{ TA } & PR & \multicolumn{2}{|r|}{ A } & & TA & PR & A & & TA & PR & A \\
\hline & & $\mathrm{t} \quad \mathrm{P}$ & $\mathrm{t} \quad \mathrm{P}$ & $\mathrm{t}$ & $\mathrm{P}$ & & $\mathrm{t} \quad \mathrm{P}$ & $\mathrm{t} \quad \mathrm{P}$ & $\mathrm{P}$ & & $\mathrm{t} \quad \mathrm{P}$ & $\mathrm{t} \quad \mathrm{P}$ & $\mathrm{P}$ \\
\hline I vs. O & & $2.65 \mathbf{0 . 0 0 5}$ & $3.28 \quad \mathbf{0 . 0 0 4}$ & 2.79 & 0.003 & & $3.95 \mathbf{0 . 0 0 5}$ & $3.99 \mathbf{0 . 0 0 3}$ & 3.730 .109 & & $4.154 \mathbf{0 . 0 0}$ & $3.84 \mathbf{0 . 0 0 1}$ & $3.10 \quad \mathbf{0 . 0 0 2}$ \\
\hline
\end{tabular}


A: UVC

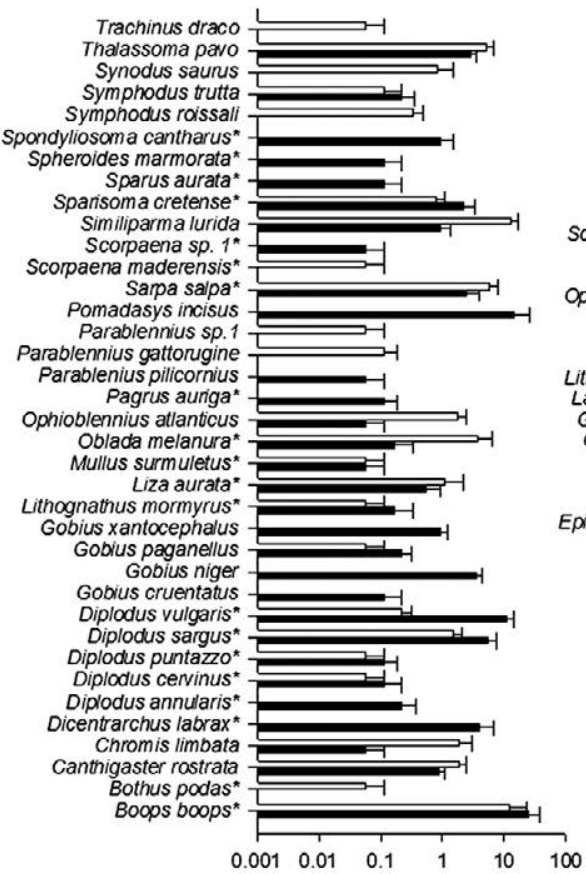

B: BC

C: FT

Fig. 3. - Mean abundances (+SE) of species at the inner (filled bars) and outer (unfilled bars) sides of marinas (pooled data) for each sampling method: UVCs (A), BCs (B) and FTs (C). Mean abundance is represented on a logarithmic scale. *, species of commercial importance.

Table 3. - Results of SIMPER analysis denoting species contributing to dissimilarities between the inner and outer sides of marinas, for each sampling technique. AvDiss, average dissimilarity; Diss/SD, ratio of average dissimilarity to standard deviation; Contr (\%), the percentage each species contributes to dissimilarities. Discriminating species are denoted for each sampling technique by highlighting the Diss/SD values close to 1 .

\begin{tabular}{|c|c|c|c|c|c|c|c|c|c|c|c|c|}
\hline & $\begin{array}{r}\text { U } \\
\text { AvDiss } \\
\text { Diss/SD }\end{array}$ & $\begin{array}{l}\mathrm{VC} \\
=78.93 \\
\text { Contr }(\%)\end{array}$ & $\begin{array}{r}\text { Gran } \\
\text { AvDiss } \\
\text { Diss/SD }\end{array}$ & $\begin{array}{l}\text { Canaria } \\
3 C \\
=70.11 \\
\text { Contr }(\%)\end{array}$ & $\begin{array}{r}\mathrm{F} \\
\text { AvDiss } \\
\text { Diss/SD }\end{array}$ & $\begin{array}{l}\mathrm{FT} \\
\mathrm{s}=91.46 \\
\text { Contr }(\%)\end{array}$ & $\begin{array}{r}\mathrm{U} \\
\text { AvDiss } \\
\text { Diss/SD }\end{array}$ & $\begin{array}{l}\text { VC } \\
=80.12 \\
\text { Contr }(\%)\end{array}$ & $\begin{array}{l}\text { Souther } \\
\text { AvDiss } \\
\text { Diss/SD }\end{array}$ & $\begin{array}{l}\text { n Portugal } \\
\text { BC } \\
\mathrm{s}=75.91 \\
\text { Contr }(\%)\end{array}$ & $\begin{array}{c}\text { AvDis } \\
\text { Diss/SD }\end{array}$ & $\begin{array}{l}\text { FT } \\
\text { s }=83.51 \\
\text { Contr }(\%)\end{array}$ \\
\hline Boops boops & 0.72 & 11.7 & 2.01 & 25.48 & 0.83 & 13.58 & - & - & - & - & - & - \\
\hline Thalassoma pavo & 1.15 & 5.1 & 2.15 & 10.33 & 1.33 & 20.03 & - & - & - & - & - & - \\
\hline Sarpa salpa & - & - & 1.29 & 10.31 & 0.76 & 14.68 & 2 & 38.79 & 5.44 & 14.5 & - & - \\
\hline Similiparma lurida & 1.46 & 12.26 & 1.94 & 8 & 0.94 & 10.36 & - & - & - & - & - & - \\
\hline Diplodus vulgaris & 1.54 & 12.76 & 1.36 & 6.23 & - & - & 1.44 & 9.85 & - & - & 2.2 & 59.96 \\
\hline Chromis limbata & - & - & 0.92 & 5.77 & 0.58 & 7.22 & - & - & - & - & - & - \\
\hline Gobius niger & 1.35 & 6.96 & - & - & - & - & 0.92 & 12.56 & - & - & 0.93 & 12.31 \\
\hline Diplodus sargus & 1.06 & 5.2 & - & - & 0.88 & 7.93 & 1.32 & 14.85 & 3.36 & 16.22 & 0.66 & 6.44 \\
\hline Atherina prebyster & - & - & - & - & - & - & - & - & 8.27 & 39.56 & - & - \\
\hline Symphodus roissali & - & - & - & - & - & - & 1.58 & 10.3 & - & - & - & - \\
\hline
\end{tabular}

most of the species found to be good discriminators by UVC were ratified by $\mathrm{BCs}$, while FTs failed to identified most of these species.

\section{Environmental predictors of fish assemblage structure}

From the seven initial environmental variables, the percentage of $\mathrm{SB}$ and $\mathrm{BB}$ were excluded due to their high correlation with the percentage of TA $(r>0.80)$. The DISTLM analysis revealed that the most important environmental variables, which had a significant influence on the fish assemblage structure, were the percentage of CCA, BA and TA, explaining $17.62 \%$, $13.98 \%$ and $8.95 \%$ of the total variation in fish assemblage structure, respectively (Table 4). The dbRDA plot suggested two clear patterns, with the first two axes explaining $89.58 \%$ of the variation out of the fit- ted model (Fig. 5A, B, Table 4). The first axis was almost perfectly correlated with the percentage of CCA. The second axis was a combination of the percentage of TA and of BA (Table 4), which were negatively correlated $(\mathrm{r}=-0.76)$; this outcome therefore suggests a sharp environmental gradient from structurally low complex algal assemblages on the inner sides of marinas to more structurally complex algal assemblages on the outer sides. In fact, the dbRDA plot effectively separated the multivariate fish assemblage data according to these gradients, with the first gradient separating samples from the outer sides of Gran Canaria from those of the inner sides and those from southern Portugal, while the second gradient separated samples from the inner and outer sides of marinas, independently of the ecoregion. The Canary damselfish (Similiparma lurida) and the ornate wrasse (Thalassoma pavo) had the highest positive correlation with the first dbRDA 
Table 4. - Pearson correlations of environmental variables and fish species with the first two dbRDA axes.

\begin{tabular}{|c|c|c|}
\hline & $\begin{array}{c}\text { dbRDA } 1 \\
\text { (22.8\% out of } \\
\text { total variation) }\end{array}$ & $\begin{array}{c}\text { dbRDA } 2 \\
\text { (13.4\% out of } \\
\text { total variation) }\end{array}$ \\
\hline \multicolumn{3}{|l|}{ Environmental variables } \\
\hline $\begin{array}{l}\% \text { CCA }(17.62 \% \text { out of total } \\
\text { variation) }\end{array}$ & -0.95 & 0.053 \\
\hline $\begin{array}{l}\% \text { TA }(13.98 \% \text { out of total } \\
\text { variation) }\end{array}$ & -0.14 & 0.77 \\
\hline $\begin{array}{l}\% \text { BA }(8.95 \% \text { out of total } \\
\text { variation) }\end{array}$ & -0.255 & -0.633 \\
\hline \multicolumn{3}{|l|}{ Species } \\
\hline Diplodus vulgaris & 0.21 & 0.64 \\
\hline Diplodus sargus & 0.18 & 0.16 \\
\hline Gobius niger & 0.31 & 0.6 \\
\hline Similiparma lurida & -0.75 & -0.01 \\
\hline Thalassoma pavo & -0.72 & 0.28 \\
\hline Sarpa salpa & 0.17 & -0.37 \\
\hline Symphodus roissali & 0.26 & -0.63 \\
\hline
\end{tabular}
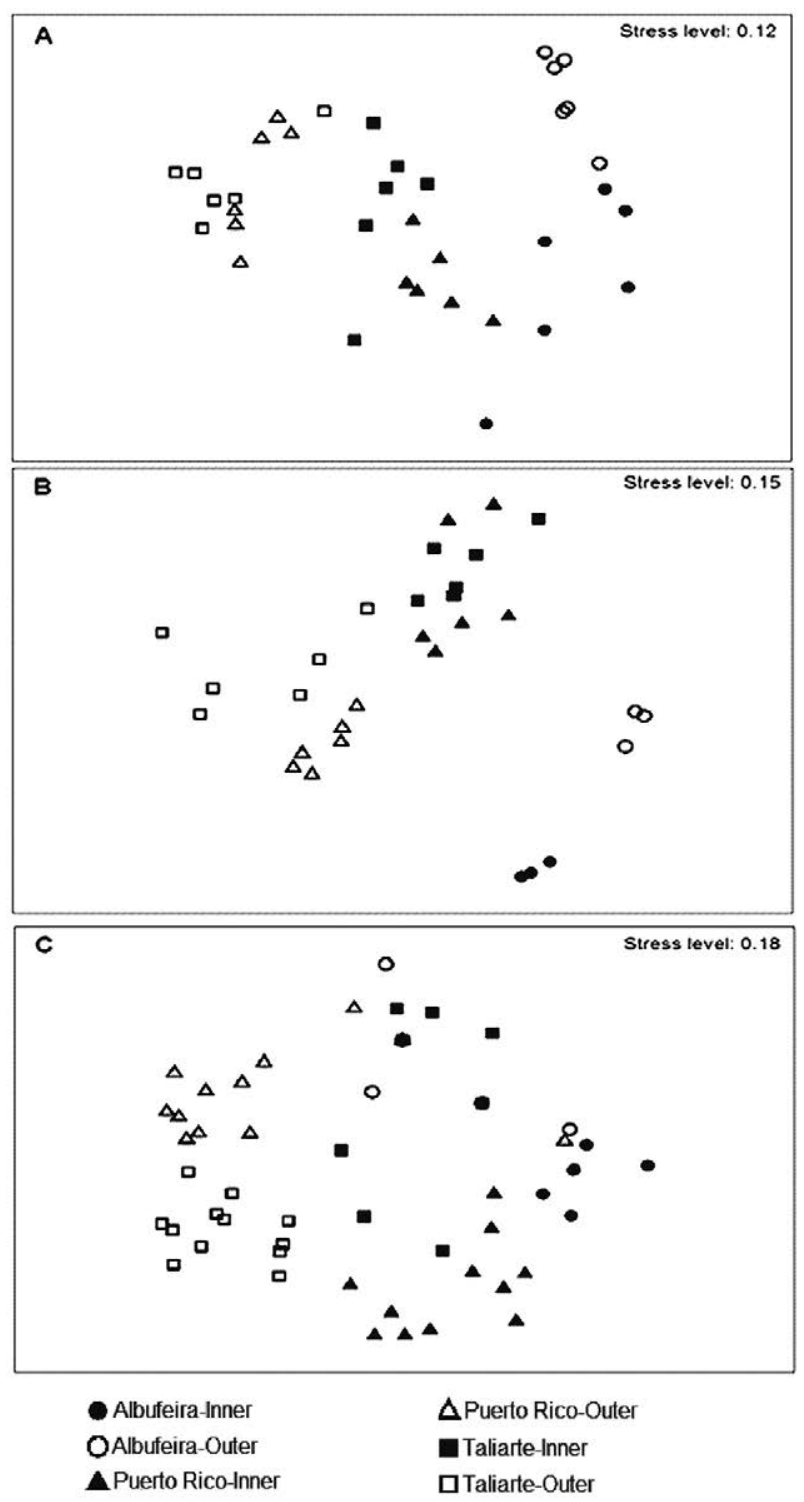

Fig. 4. - MDS ordination plots showing similarities in fish assemblage structure between the inner (filled symbols) and outer (unfilled symbols) sides of marinas: Puerto Rico, Taliarte and Albufeira for each sampling method: UVCs (A), BCs (B) and FTs (C).
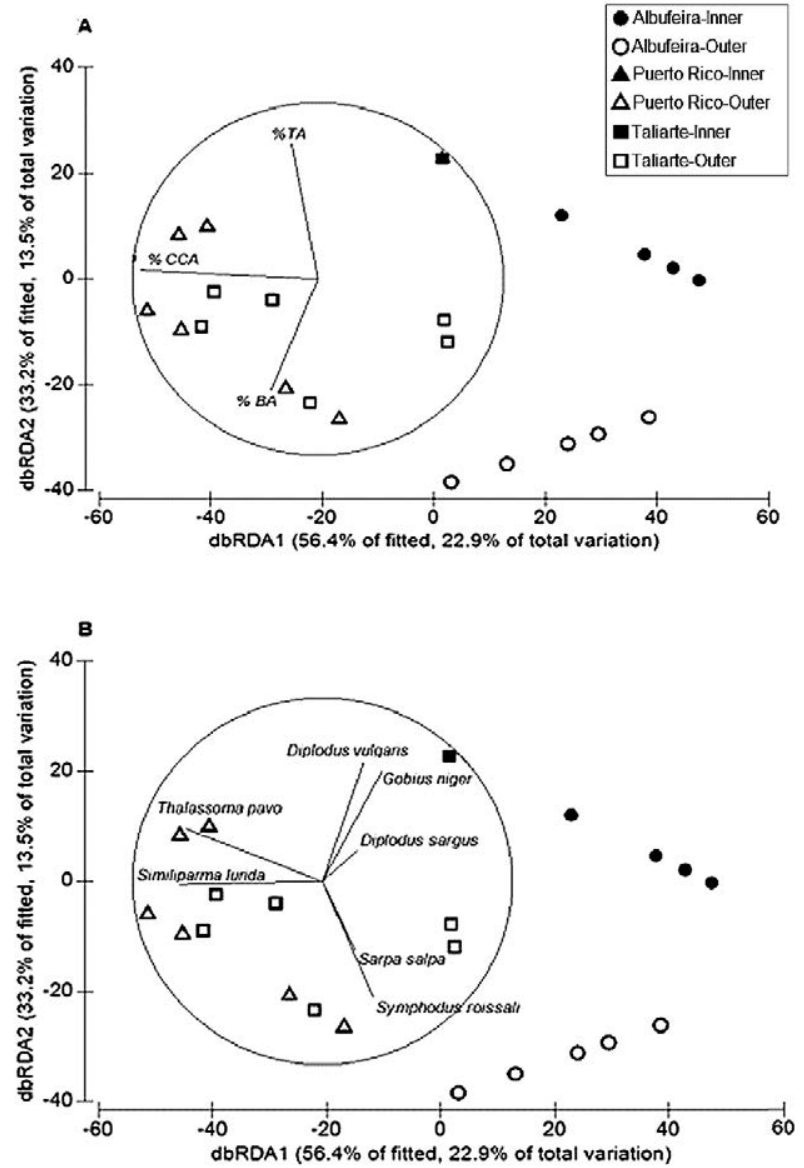

Fig. 5. - dbRDA ordination plots relating significant environmental variables from the DISTLM model and fish assemblage structure for UVCs. A, vectors represent the super-imposed partial correlations of significant environmental variables. B, vectors represent super-imposed raw Pearson correlations of the species identified as important contributors to dissimilarities between the inner (filled symbols) and outer (unfilled symbols) sides of the marinas: Puerto Rico, Taliarte and Albufeira. CCA, crustose coralline algae; BA, bush-like algae; TA, turf algae.

axis (Fig. 5B, Table 4); these two species characterized the outer sides of marinas from Gran Canaria. The two-banded seabream (Diplodus vulgaris) and the black goby (Gobius niger) had the highest positive correlations with the second dbRDA axis (Fig. 5B, Table 4 ) and characterized the inner sides of marinas at both regions along with $D$. sargus. In southern Portugal, two species were negatively correlated with this axis, the saupe (Sarpa salpa) and the five-spotted wrasse (Symphodus roissali) (Fig. 5B), and therefore characterized the outer sides of marinas.

\section{DISCUSSION}

In this study, we found that differences in the number and the relative abundance of fish species between the inner and outer sides of marinas varied not only from marina to marina, but also according to the sampling method. Inter-marina variation is not surprising, as they are located tens of kilometres apart in Gran Canaria and thousands of kilometres from the marina in southern Portugal. Thus, the observed spatial differences might be related to natural variability, resulting 
from the interaction of physical and biological processes among locations far away (Lincoln-Smith et al. 1991, Tuya et al. 2011).

UVCs and BC recorded a comparable number and relative abundances of fish species, which in turn were much greater than those recorded by FTs. This larger amount of data, and in particular the lower amount of 0 counts, results in a larger statistical power to accurately detect significant patterns. Thus, previous studies on tropical and temperate regions have proved BCs to be a better method than FTs for detecting differences in the structure of fish communities (Harvey et al. 2012, Wakefield et al. 2013). In the case of the marina located in southern Portugal, however, the efficiency of UVCs and BCs was lower, resulting in a lower number and relative abundance of species recorded, which were comparable to those recorded by FTs. This might be attributed to increased turbidity in this region, which greatly reduce the efficiency of visual techniques (Murphy and Jenkins 2010). Greater efficiencies of UVCs and BCs are not surprising, especially in sampling complex habitat types such as artificial structures. UVCs allow a diverse set of habitats to be sampled, and they are therefore more likely to encounter both pelagic and benthic species (Langlois et al. 2010, Stobart et al. 2007, Colton and Swearer 2010). Furthermore, their active nature favours the encounter of cryptic species, which are usually hidden under crevices or in holes (Colton and Swearer 2010, Lowry et al. 2012). BCs depend on the species-specific movement of individuals within the field of view. This method has proved to be effective at recording highly piscivorous species, which usually avoid divers; it has also been shown to record herbivorous and omnivorous species (Cappo et al. 2006, Langlois et al. 2010). We also found that UVCs recorded a greater number of cryptic species, while $\mathrm{BCs}$ recorded more piscivorous species. Conversely, the high selectivity and variable catchability of FTs results in a high proportion of zero records for many species, especially non-target species that are not attracted to the bait (Harvey et al. 2012, Bacheler et al. 2013). Furthermore, the complex topography of artificial structures found at marinas (e.g. large-sized blocks) means that traps need to be located adjacent to them, so they rely on fish leaving the complex shelter provided by these structures (Wakefield et al. 2013). It must be noted that both BCs and FTs are only able to provide relative abundance estimates due to the complexities of calculating the dispersion range of the bait plume, while UVCs allow for a suitable estimation of the sampling area.

Overall, despite differences between methods, the multivariate analysis consistently (i.e. across sampling methods) discriminated fish assemblages between the inner and outer sides of all marinas. In the MDS plots, UVCs and BCs discriminated fish assemblages between regions, although this separation was more noticeable in the BC plot. Conversely, FT data tended to misclassify samples, and no apparent separation between regions was observed, clearly suggesting a weak discriminating power of this technique.
At Gran Canaria, two small-sized species (Thalassoma pavo and Similiparma lurida) consistently (i.e. across sampling methods) contributed to dissimilarities between the inner and outer sides of marinas; in southern Portugal, Sarpa salpa and Symphodus roissali dominated the outer sides of marinas. Similiparma lurida is a common species inhabiting shallow-water rocky reefs in the Canarian archipelago, especially those covered by thick vegetation (García-Mederos et al. 2016). Similarly, like other labrid species, such as $S$. roissali, $T$. pavo prefers rocky substrates with high algal coverage, which are used by adults to build their nests and forage (Jones 1984). Sarpa salpa also prefers rocky substrates covered by dense vegetation, where juveniles can find small invertebrates to feed and adults marine plants to graze (Peirano et al. 2001). As in our results, Guidetti (2004) found T. pavo and $S$. salpa mostly associated with exposed sides of breakwaters from the Mediterranean. This pattern of specieshabitat association could be attributed, as shown in the dbRDA analysis, to a sharp gradient in the composition and structure of algal assemblages, from low structurally complex (i.e. TA) at the inner to more structurally complex assemblages (i.e. CCA and BA) at the outer sides of marinas. In fact, we found significant partial correlations of these species with the dbRDA axis defining a sharp gradient in algal assemblages. Similarly, Pizzolon et al. (2008) found differences in fish assemblage structure between the landward and seaward sides of breakwaters in the Adriatic Sea, and attributed these differences to variation in environmental characteristics. Furthermore, the large topographic elements, i.e. large concrete blocks, on the outer sides of marinas could potentially be used by juveniles and adults of these species, providing refuge in the ledges between adjacent boulders (Scharf et al. 2006). However, the high level of variance unexplained by the model (DISTLM analysis) suggests the presence of additional environmental factors that could contribute to explaining variation in the fish assemblage structure.

In both regions, Diplodus vulgaris, Diplodus sargus and Gobius niger were important contributors to dissimilarities between the inner and outer sides of marinas, in particular characterizing the inner sides. Gobius niger is usually found over low complexity habitats, e.g. sandy and muddy bottoms, with a high concentration of organic material (da Cunha and Antunes 2008), i.e. conditions typically found on the inner sides of marinas. Interestingly, all the individuals of $D$. vulgaris and D. sargus found on the inner sides of marinas were below their length at first maturity (Supplementary material Table S1). Bouchoucha et al. (2016) demonstrated that marinas can provide a suitable nursery habitat for juveniles of these species in the Mediterranean. This might be favoured by the high plasticity in habitat requirements of juveniles of the genus Diplodus, which may allow their successful recruitment and further growth on the inner sides of marinas. Thus, stable conditions inside marinas, in conjunction with high food availability often found in marinas (Connell and Glasby 1999, Clynick et al. 2007), can contribute to the successful recruitment, 
growth and survival of juveniles of Diplodus species. Nonetheless, due to the limitations of our study, which was carried out over a short time window, we cannot ascertain the value of marinas as a nursery habitat. In fact, studies in the Mediterranean have shown that juveniles of $D$. vulgaris settle in February-May and reach pre-dispersal size between late July and early August, when they leave nursery grounds (Ventura et al. 2014). Thus, it is likely that the presence of this species on the inner sides of marinas results from migration of individuals from adjacent rocky reefs, and marinas, like other artificial structures, could just act as attracting devices (Bohnsack 1989, Rilov and Benayahu 2000). Further investigations on the value of marinas as nursery grounds are essential, as these species have a high commercial value both at the Canary Islands and in southern Portugal. The results would be especially relevant for the Canary Islands, where information on the settlement period and nursery areas of these species is limited.

In summary, our study supports the use of nonextractive techniques such as UVCs and BCs over traditional fishing techniques such as FTs, particularly for studies that incorporate artificial structures. The higher efficiencies of these sampling techniques allows for a better representation of fish assemblages and thus a greater discriminating power. This information is of great interest for developing sound monitoring programmes on the effects of artificial structures on fish communities.

\section{ACKNOWLEDGEMENTS}

We thank the Biodiversity and Conservation Group of the Universidad de Las Palmas de Gran Canaria (IUECOAQUA), as well as the Coastal Fisheries Research Group (CFRG) of the Centro de Ciências Do Mar (CCMAR, UALG), for all the logistic support provided during this study. Two anonymous reviewers provided positive feedback on a previous draft of this paper.

\section{REFERENCES}

Airoldi L., Beck M.W. 2007. Loss, status and trends for coastal marine habitats of Europe. In: Gibson R.N., Atkinson R.J.A., Gordon J.D.M. (eds), Oceanography and marine biology, Vol 45. CRC Press-Taylor and Francis Group, Boca Raton, FL, pp. 345-405.

Anderson M.J. 2001. A new method for non-parametric multivariate analysis of variance. Austral. Ecol. 26: 32-46.

Bacheler N.M., Schobernd C.M., Schobernd Z.H., et al. 2013. Comparison of trap and underwater video gears for indexing reef fish presence and abundance in the southeast United States. Fish. Res. 143: 81-88. https://doi.org/10.1016/j.fishres.2013.01.013

Bohnsack J.A. 1989. Are high densities of fishes at artificial reefs the result of habitat limitation or behavioural preferences? Bull. Mar. Sci. 44: 631-645.

Bouchoucha M., Darnaude A.M., Gudefin A., et al. 2016. Potential use of marinas as nursery grounds by rocky fishes: insights from four Diplodus species in the Mediterranean. Mar. Ecol. Prog. Ser. 547: 193-209. https://doi.org/10.3354/meps 11641

Cappo M., Harvey E., Shortis M. 2006. "Counting and measuring fish with baited video techniques - an overview". Australian Society for Fish Biology; 2006 Workshops Proceedings. Australia.

Carr M.H., Hixon M.A. 1997. Artificial reefs: the importance of comparisons with natural reefs. Fisheries 22: 28-33.
https://doi.org/10.1577/1548-8446(1997)022<0028:ARTIOC> 2.0.CO;2

Cenci E., Pizzolon M., Chimento N., et al. 2011. The influence of a new artificial structure on fish assemblages of adjacent hard substrata. Est. Coast. Shelf. Sci. 91: 133-149. https://doi.org/10.1016/j.ecss.2010.10.009

Chambers J.M., Hastie T.J. 1993. Statistical models in S. Chapman and Hall.

Clarke K.R., Warwick R.M. 2001. Change in marine communities: an approach to statistical analysis and interpretation, 2nd edn. PRIMER-E, Plymouth.

Clarke K.R., Somerfield P.J., Chapman M.G. 2006. On resemblance measures for ecological studies, including taxonomic dissimilarities and a zero-adjusted Bray-Curtis coefficient for denuded assemblages. J. Exp. Mar. Biol. Ecol. 330: 55-80. https://doi.org/10.1016/j.jembe.2005.12.017

Clynick B.G. 2006. Assemblages of fish associated with coastal marinas in north-western Italy. J. Mar. Biol. Assoc. UK. 86: 847-852. https://doi.org/10.1017/S0025315406013786

Clynick B.G. 2008. Characteristics of an urban fish assemblage: distribution of fish associated with coastal marinas. Mar. Environ. Res. 65: 18-33. https://doi.org/10.1016/j.marenvres.2007.07.005

Clynick B.G., Chapman M.G., Underwood A.J. 2007. Effects of epibiota on assemblages of fish associated with urban structures. Mar. Ecol. Prog. Ser. 332: 201-210. https://doi.org/10.3354/meps332201

Colton M.A., Swearer S.E. 2010. A comparison of two survey methods: differences between underwater visual census and baited remote underwater video. Mar. Ecol. Prog. Ser. 400: 19-36. https://doi.org/10.3354/meps08377

Connell S.D., Glasby T.M. 1999. Do urban structures influence local abundance and diversity of subtidal epibiota? A case study from Sydney Harbour, Australia. Mar. Environ. Res. 47: 373-387. https://doi.org/10.1016/S0141-1136(98)00126-3

Courrat A., Lobry J., Nicolas D., et al. 2009. Anthropogenic disturbance on nursery function of estuarine areas for marine species. Est. Coast. Shelf. Sci. 81: 179-190. https://doi.org/10.1016/j.ecss.2008.10.017

da Cunha P.L., Antunes M.M. 2008. Notes on Gobiidae (Teleostei) from soft bottoms of the Portuguese coast. Cybium 32: 309-315.

Edgar G.J., Barrett N.S., Morton A.J. 2004. Biases associated with the use of underwater visual census techniques to quantify fish density and size-structure. J. Exp. Mar. Biol. Ecol. 308: 269-290. https://doi.org/10.1016/j.jembe.2004.03.004

García-Mederos A.M., Tuya F., Tuset V.M. 2016. Life-history strategies of a conspicuous reef fish, the Canary damsel Similiparma lurida (Pomacentridae) in the northeastern Atlantic. Sci. Mar. 80: $57-68$. https://doi.org/ 10.3989/scimar.04343.28A

Gonçalves J.M.S., Bentes L., Coelho R., et al. 2003. Age and growth, maturity, mortality and yield-per-recruit for two banded bream (Diplodus vulgaris Geoffr.) from the south coast of Portugal. Fish. Res. 62: 349-359. https://doi.org/10.1016/S0165-7836(02)00280-1

González J.A., Pajuelo J.G., Lorenzo J.M., et al. 2012. Talla mínima de captura: peces, crustáceos y moluscos de interés pesquero en Canarias: una propuesta científica para su conservación. Consejería de Agricultura, Ganadería Pesca y Alimentación, 248 pp.

Guidetti P. 2004. Fish assemblages associated with coastal defence structures in south-western Italy (Mediterranean Sea). J. Mar. Biol. Assoc. UK. 84: 669-670. https://doi.org/10.1017/S0025315404009725h

Halpern B.S., Walbridge S., Selkoe K.A., et al. 2008. A global map of human impact on marine ecosystems. Science 319: 948-952. https://doi.org/10.1126/science.1149345

Harmelin-Vivien M.L.,Harmelin J.G., Chauvet C., et al. 1985. Evaluation visuelle des peuplements et populations de poissons: méthodes et problèmes. Rev. Ecol. Terre Vie 40: 467-539.

Harvey E.S., Shortis M., Stadler M., et al. 2002. A comparison of the accuracy and precision of measurements from single and stereo-video systems. Mar. Tech. Soc. J. 36: 38-49. https://doi.org/10.4031/002533202787914106

Harvey E.S., Newman S.J., McLean D.L., et al. 2012. Comparison of the relative efficiencies of stereo-BRUVs and traps for sampling tropical continental shelf demersal fishes. Fish. Res. 125: 108-120. https://doi.org/10.1016/j.fishres.2012.01.026 
Jones G.P. 1984. Population ecology of the temperate reef fish Pseudolabrus celidotus Bloch and Schneider (Pisces: Labridae). I. Factors influencing recruitment. J. Exp. Mar. Biol. Eco1. 75: 257-276.

Langlois T.J., Harvey E.S., Fitzpatrick B., et al. 2010. Cost-efficient sampling of fish assemblages: comparison of baited video stations and diver video transects. Aquat. Biol. 9: 155-168. https://doi.org/10.3354/ab00235

Leathwick J.R., Elith J., Hastie T. 2006. Comparative performance of generalised additive models and multivariate adaptive regression splines for statistical modelling of species distributions. Ecol. Model. 199: 188-196. https://doi.org/10.1016/j.ecolmodel.2006.05.022

Lincoln-Smith M.P., Bell J.D., Hair C.A. 1991. Spatial variation in abundance of recently settled rocky reef fish in southeastern Australia: implications for detecting change. Mar. Ecol. Prog. Ser. 77: 95-103 https://doi.org/10.3354/meps077095

Lowry M., Folpp H., Gregson M., et al. 2012. Comparison of baited remote underwater video (BRUV) and underwater visual census (UVC) for assessment of artificial reefs in estuaries. J. Exp. Mar. Biol. Ecol. 416: 243-253. https://doi.org/10.1016/j.jembe.2012.01.013

Monteiro C., Lam Hoai T., Lasserre G. 1987. Distribution chronologique des poissons dans deux stations de la lagune Ria Formosa (Portugal). Oceanol. Acta 10: 359-371.

Murphy H.M., Jenkins G.P. 2010. Observational methods used in marine spatial monitoring of fishes and associated habitats: a review. Mar. Freshw. Res. 61: 236-252. https://doi.org/10.1071/MF09068

Ohlhorst S.L., Liddell W.D., Taylor R.J., et al. 1988. Evaluation of reef census techniques. Proc. 6th Intl. Coral Reef. Symp. 2: 319-324. Townsville, Australia.

Pastor J., Koeck B., Astruch P., et al. 2013. Coastal man-made habitats: potential nurseries for an exploited fish species, Diplodus sargus (Linnaeus, 1758). Fish. Res. 148: 74-80. https://doi.org/10.1016/j.fishres.2013.08.014

Peirano A., Niccolai I., Mauro R., et al. 2001. Seasonal grazing and food preference of herbivores in a Posidonia oceanica meadow. Sci. Mar. 65: 367-374. https://doi.org/10.3989/scimar.2001.65n4367

Pizzolon M., Cenci E., Mazzoldi C. 2008. The onset of fish colonization in a coastal defence structure (Chioggia, Northern Adriatic Sea). Est. Coast. Shelf. Sci. 78: 166-178. https://doi.org/10.1016/j.ecss.2007.11.014

Rilov G., Benayahu Y. 2000. Fish assemblage on natural versus vertical artificial reefs: the rehabilitation perspective. Mar. Biol. 136: $931-942$. https://doi.org/10.1007/s002279900250

Scharf F.S., Manderson J.P., Fabrizio M.C. 2006. The effects of seafloor habitat complexity on survival of juvenile fishes: Speciesspecific interactions with structural refuge. J. Exp. Mar. Biol. Ecol. 335: 167-176. https://doi.org/10.1016/j.jembe.2006.03.018

Seitz R.D., Wennhage H., Bergström U., et al. 2014. Ecological value of coastal habitats for commercially and ecologically important species. ICES. J. Mar. Sci. 71: 648-665. https://doi.org/10.1093/icesjms/fst152
Steneck R.S., Dethier M.N. 1994. A functional group approach to the structure of algal-dominated communities. Oikos 69: 476-498. https://doi.org/10.2307/3545860

Stobart B, Garcia-Charton J.A., Espejo C., et al. 2007. A baited underwater video technique to assess shallow-water Mediterranean fish assemblages: Methodological evaluation. J. Exp. Mar. Biol. Ecol. 345: 158-174. https://doi.org/10.1016/j.jembe.2007.02.009

Tuya F., Haroun R.J. 2006. Spatial patterns and response to wave exposure of shallow water algal assemblages across the Canarian Archipelago: a multi-scaled approach. Mar. Ecol. Prog. Ser. 311: 15-28. https://doi.org/10.3354/meps311015

Tuya F., Boyra A., Sanchez-Jerez P., et al. 2005. Multivariate analysis of the bentho-demersal ichthyofauna along soft bottoms of the Eastern Atlantic: comparison between unvegetated substrates, seagrass meadows and sandy bottoms beneath sea-cage fish farms. Mar. Biol. 147: 1229-1237. https://doi.org/10.1007/s00227-005-0018-1

Tuya F., Wernberg T., Thomsen M.S. 2011. The relative influence of local to regional drivers of variation in reef fishes. J. Fish. Biol. 79: 217-234 https://doi.org/10.1111/j.1095-8649.2011.03015.x

Underwood A.J. 1981. Techniques of analysis of variance in experimental marine biology and ecology. Oceanogr. Mar. Biol. Annu. Rev. 19: 513-605.

Ventura D., Jona Lasinio G., Ardizzone G. 2014. Temporal partitioning of microhabitat use among four juvenile fish species of the genus Diplodus (Pisces: Perciformes, Sparidae). Mar. Ecol. 36: $1-20$.

Wakefield C.B., Lewis P.D., Coutts T.B., et al. 2013. Fish assemblages associated with natural and anthropogenically-modified habitats in a marine embayment: comparison of baited videos and opera-house traps. PloS ONE 8: e59959. https://doi.org/10.1371/journal.pone.0059959

Watson D.L., Harvey E.S., Anderson M.J., et al. 2005. A comparison of temperate reef fish assemblages recorded by three underwater stereo-video techniques. Mar. Biol. 148: 415-425. https://doi.org/10.1007/s00227-005-0090-6

\section{SUPPLEMENTARY MATERIAL}

The following supplementary material is available through the online version of this article and at the following link: http://scimar.icm.csic.es/scimar/supplm/sm04540esm.pdf

Fig. S1. - Fish traps used during this study.

Fig. S2. - Baited cameras used during this study.

Table S1. - Total abundance (N, number of individuals), size range $(\mathrm{TL}$ in $\mathrm{cm})$ and first maturity sizes $\left(\mathrm{SFM}_{50}\right)$ of Diplodus sargus and Diplodus vulgaris recorded by underwater visual censuses (UVCs) and fish traps (FTs). SFM 5 was obtained from the local literature (Gonçalves et al. 2003, González et al. 2012). 


\section{Marinas as habitats for nearshore fish assemblages: comparative analysis of underwater visual census, baited cameras and fish traps}

Néstor E. Bosch, Jorge Gonçalves, Fernando Tuya, Karim Erzini

Supplementary material 


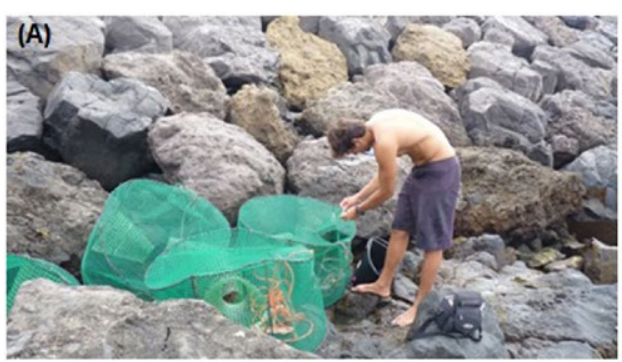

(B)

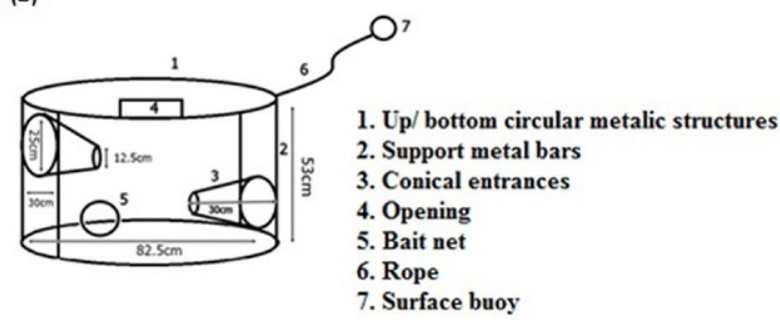

Fig. S1. - Fish traps used during this study.

Table S1. - Total abundance (N, number of individuals), size range $(\mathrm{TL}$ in $\mathrm{cm})$ and first maturity sizes $\left(\mathrm{SFM}_{50}\right)$ of Diplodus sargus and Diplodus vulgaris recorded by underwater visual censuses (UVCs) and fish traps (FTs). SFM ${ }_{50}$ was obtained from the local literature (Gonçalves et al. 2003, González et al. 2012).

\begin{tabular}{lccccc}
\hline \multirow{2}{*}{ Species } & \multicolumn{3}{c}{$\begin{array}{c}\text { Total } \mathrm{n}^{\circ} \text { of } \\
\text { individuals (N) }\end{array}$} & \multicolumn{3}{c}{ Size range (cm) } & \multicolumn{2}{c}{ First maturity } \\
& UVCs & FTs & UVCs & FTs & \\
SFM $_{50}(\mathrm{~cm})$ & \\
\hline Diplodus sargus & 94 & 41 & $5-15$ & $5.8-10.9$ & 21.6 \\
Diplodus vulgaris & 185 & 42 & $5-15$ & $6.6-12.5$ & 20.9 \\
\hline
\end{tabular}

(A)

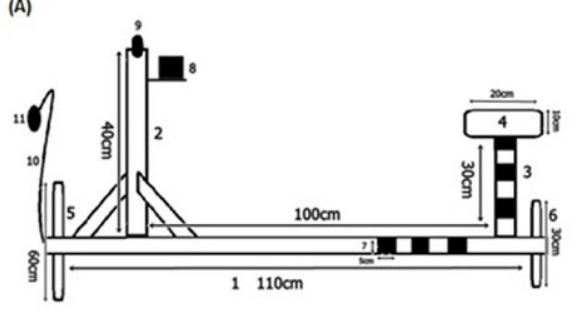

1. Main bar. condary Gopro bar. 3. Secondary bait ber.
4. PVC bait tube. - Anterifor stablizer bor. 7.- Posterior 8- Gopro. 11.- Rope. Surface buoy.

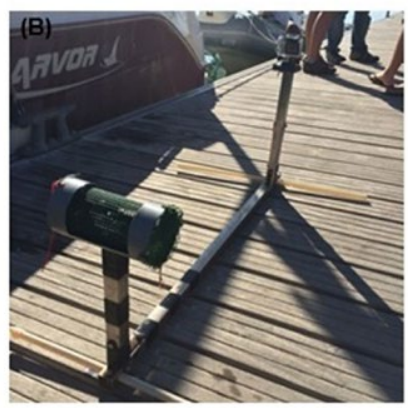

Fig. S2. - Baited cameras used during this study. 